\title{
HUBUNGAN KESEPIAN DAN PENGUNGKAPAN DIRI DI INSTAGRAM PADA DEWASA YANG BELUM MENIKAH
}

\author{
Nora Anggraeni ${ }^{1}$, Uun Zulfiana ${ }^{2}$ \\ ${ }^{1,2}$ Fakultas Psikologi Universitas Muhammadiyah Malang \\ 1'noraanggraedy@gmail.com, ${ }^{2}$ uun@umm.ac.id
}

\begin{abstract}
Abstrak. Penggunaan media sosial salah satunya instagram sebagai wadah berbagi informasi untuk mengatasi perasaan kesepian yang dirasakan akibat ketiadaan hubungan dengan individu lain di dunia nyata. Sebagian individu yang telah memasuki fase dewasa masih belum mampu untuk memenuhi kebutuhan berhubungan dengan orang lain. Salah satu cara yang dilakukan dengan membentuk komitmen untuk membangun sebuah pernikahan. Tujuan dalam penelitian ini untuk mengetahui hubungan antara kesepian dengan pengungkapan diri di instagram pada dewasa yang belum menikah. Penelitian ini merupakan penelitian kuantitatif korelasional dengan sampel sejumlah 260 orang yang diambil menggunakan teknik nonprobability sampling jenis purposive sampling. Pengambilan data menggunakan skala pengungkapan diri dan kesepian yang dianalisis menggunakan korelasi Spearman. Hasil menunjukkan tidak ada hubungan antara kesepian dan pengungkapan diri di instagram pada dewasa yang belum menikah.
\end{abstract}

Kata Kunci: Kesepian, Pengungkapan Diri, Dewasa Belum Menikah

Abstract. Exchanging information is one of the leading reasons social media is frequently used nowadays. Instagram for instance, its presence is not only for sharing information to others but also for surmounting solitude as result of social interaction absence in reality. For individuals who have been indicated as adults, the ability to do interaction to others is incapable, marriage commitment as an example. This current study is aimed to find out the relation between loneliness and self-disclosure through instagram for unmarried adults. In this current study used correlational quantitative method in which 260 research participants were recruited by employing nonprobability sampling technique with purposive sampling type. The assembled data taken by using scale of loneliness and self-disclosure and analysed by way of Spearmen correlation. The results have shown that there are no relations between solitude and self-disclosure through instagram for unmarried adults.

Keywords: Loneliness, Self-disclosure, Unmarried Adults 
Era modern seperti sekarang ini dengan perkembangan internet terutama media sosial sangat berpengaruh pada kehidupan sehari-hari. Manusia sebagai makhluk sosial banyak melakukan interaksi berupa sosialisasi baik itu di dunia maya sekalipun. Kecanggihan teknologi membuat penggunanya mudah untuk melakukan interaksi hanya dengan mengakses menggunakan telepon pintar, tablet, komputer, maupun laptop. Interaksi yang dilakukan oleh pengguna internet aktif atau biasa disebut dengan istilah netizen ini dapat berupa dibagikannya momen seperti status, foto maupun video pendek kepada para pengguna lain menggunakan fitur sosial media dengan memanfaatkan beragam media sosial seperti instagram, facebook, youtube, twitter, line, whatspp, path, askfm dan sebagainya sehingga dapat menghubungkan komuikasi antar individu.

Pengguna internet di Indonesia pada tahun 2013 telah mencapai 63 juta orang. Beberapa wilayah di Indonesia seperti Lombok dan Malang sama-sama menyumbang angka penggunaan internet mencapai 160.000 pengguna. Dari angka tersebut 95 persennya menggunakan internet untuk mengakses jejaring sosial (Kominfo.go.id, 2013). Sedangkan survei pada tahun 2016 yang dilakukan oleh Asosiasi Penyelenggara Jasa Internet Indonesia, dapat diketahui bahwa jumlah penggunaan internet di Indonesia mencapai 132,7 juta, di wilayah Bali dan Nusa Tenggara mencapai 6,1 juta pengguna sedangkan wilayah Pulau Jawa mencapai 86,3 juta. Adapun pengguna internet didominasi oleh usia 35-44 tahun dengan jumlah 29,2\%. Pada penggunaan internet banyak digunakan untuk mengakses media sosial sejumlah 129,2 juta dengan jenis konten facebook 71,6 juta dan diikuti oleh instagram sejumlah 19,9 juta serta youtube 14,5 juta (APJII, 2016). Survei dalam penelitian yang dilakukan oleh Farber \& Nitzbrug (2016) kepada salah satu subjek yakni dewasa berusia (18-29) menunjukkan bahwa penyampaian informasi pada media sosial khususnya pada pengguna facebook dilakukan melalui postingan emosi.

Instagram adalah sebuah aplikasi jejaring sosial berbasis foto dan video yang memungkinkan pengguna untuk menerapkan filter digital, dan membagikannya ke berbagai layanan jejaring sosial lain. Instagram mengumumkan bahwa pada tahun 2016 penggunannya telah berkembang menjadi lebih dari 500 juta pengguna, 300 juta di antaranya menggunakan instagram setiap hari dan berkembang secara global dengan 80 persen pengguna instagram tinggal di luar wilayah Amerika Serikat. Instagram sendiri digunakan sebagai bentuk komunikasi untuk menangkap berbagi moment dan digunakan untuk membantu mengekspresikan diri para penggunanya melalui fitur-fiturnya (instagram-press.com).

Penggunaan media sosial seperti instagram tidak selamanya dianggap baik, terkadang dapat memunculkan permasalahan seperti pemberian informasi diri yang disebarkan secara luas, cendrung berlebihan dan tidak terbatas termasuk dengan orang yang tidak dikenal sekalipun. Dengan demikian, hal ini membuat penggunanya tidak malu untuk mencurahkan perasaan mereka secara umum melalui postingan foto, video atau status pada dunia maya daripada harus face to face secara langsung. Hal ini sejalan dengan penelitian Krasnova (dalam Prawesti \& Dewi, 2016) yang mengatakan bahwa motivasi seseorang menggunakan situs jejaring sosial karena merasakan kenyamanan dalam menceritakan informasi pribadinya. Penggunaan jejaring sosial digunakan untuk membangun maupun memperluas hubungan sosial melalui dunia maya dan berfungsi untuk menjadi media dalam menyampaikan informasi. 
Istilah dalam psikologi yang menjelaskan tentang kegiatan dalam membagi atau menyampaikan informasi dengan orang lain ini disebut dengan pengungkapan diri atau self disclosure. Dayakisni dan Hudaniah (2009) menjelaskan pengungkapan diri yaitu kegiatan dalam membagi informasi yang akrab dengan orang lain berupa berbagi topik seperti informasi perilaku, sikap, perasaan, keinginan, motivasi dan ide yang sesuai dan terdapat dalam diri orang yang bersangkutan berupa deskriptif maupun evaluatif.

Pengungkapan diri pada seorang individu, umumnya berkaitan dengan keintiman yang dialami pada masa dewasa. Santrock (2011) menjelaskan keterbukaan diri dan berbagi pikiran personal merupakan salah satu tanda dari sebuah keintiman. Sears, Freedman \& Peplau (1985) juga menjelaskan bahwa pengungkapan diri lebih sering dilakukan pada pasangan hidup atau sahabat dan pengungkapan diri yang dilakukan dapat menimbulkan rasa suka sehingga berkembang suatu hubungan dangkal hingga menjadi akrab. Tahuntahun pertama masa dewasa adalah saat ketika seorang individu biasanya membangun hubungan yang intim dengan individu lain dengan diikuti perkembangan berketurunan. Aspek penting dari hubungan ini adalah komitmen individu satu sama lain. Pada rentang usia yang akan memasuki umur 25 tahun, seorang individu mulai untuk melakukan eksplorasi identitas terutama dengan cinta dan pekerjaan (dalam Santrock, 2002; \& Alwisol, 2008).

Pengungkapan diri yang dilakukan di media sosial berjenis instagram memiliki kesamaan dengan jenis media sosial lainnya. Sejalan dengan salah satu penelitian yang dilakukan oleh Al-Kandari, Melkote \& Sharif (2016) mengemukakan bahwa pada dasarnya instagram menyediakan kategori kebutuhan dan motif yang serupa dengan media sosial lain untuk mengungkapkan diri seperti ekspresi diri, interaksi sosial, hiburan dan sebagai petukaran pendapat, namun yang membedakannya dengan jenis media sosial lainnya yaitu fitur untuk mensingkronkan foto dengan jenis media sosial lain serta kebutuhan dalam fotografi yang dianggap sebagai unggulan pada pengguaannya. Fasilitas dalam penggunaan instagram berupa gambar dimanfaatkan pada penggunaan judul untuk mencerminkan suasana hati yang spesifik menggambarkan momen seorang individu. Selain itu dijelaskan juga bahwa konteks gambar pada penggunaan media sosial berkaitan dengan perbedaan antar budaya, frekuensi penggunaan instagram yang tinggi dianggap dapat meningkatkan tingkat pengungkapan diri, serta fotografi dapat menciptakan lebih banyak kesempatan untuk individu dalam melakukan interpretasi karena pemahaman yang berbeda pada sebuah foto yang memberikan simbolis dari pengalaman sensorik dan emosional dibandingkan teks yang hanya dapat menawarkan pernyataan.

Penggunaan media sosial yang dilakukan oleh seorang individu tentu akan berdampak psikologis. Pengungkapan diri yang positif seperti memberikan selamat, pujian atau motivasi pada situs jejaring sosial memberikan manfaat pada peningkatan kesehatan fisik, mental, pengalaman emosional sehingga dapat mengatur ulang pikiran dan perasaan tentang pengalaman traumatik atau hambatan yang tersembunyi dalam pikiran individu, sedangkan pengungkapan diri yang negatif pada media sosial seperti mencela orang lain, berkata kotor dapat berakibat pada penolakan orang lain, cemooh, dihindari bahkan dikucilkan dari pergaulan sosial (dalam Mafazi \& Nuqul, 2017). 
Pengungkapan diri yang dilakukan oleh seorang individu di media sosial akan berdampak positif dan juga negatif. Individu yang melakukan pengungkapan diri secara berlebihan menyebabkan pengabaian, penolakan, hilangnya kontrol bahkan pengkhianatan (Taylor, Peplau \& Sears 2009). Namun pengungkapan diri yang dilakukan di media sosial juga dapat menimbulkan dampak positif pada penggunanya. Baru-baru ini dikabarkan bahwa seorang wanita mendadak menjadi terkenal karena telah melakukan curhatan berbentuk video yang mengeluhkan kegiatan sehari-hari seperti memasak, mengurus anak, membersihkan rumah dan keinginan agar suaminya mampu untuk mengajaknya jalanjalan ke mall atau minimarket. Akibat dari curhatannya wanita tersebut dibanjiri dengan berbagai macam tawaran untuk muncul pada acara televisi (tribunnews.com, 2018).

Berdasarkan uraian kasus yang dialami oleh penggunaan internet, tentunya tidak terlepas dari kontrol terhadap diri sendiri. Blachnio dan Przepiorka (2016) menjelaskan seorang individu yang memiliki cukup kontrol diri dapat menggunaan internet dengan cara yang sehat. Selain itu dijelaskan juga seseorang individu yang menggunakan media sosial dapat melarikan diri dari masalah pikiran dan perilaku kedunia realistis virtual yang mampu meningkatkan suasana hati seorang individu.

Varnali dan Toker (2015) menjelaskan faktor seseorang dalam melakukan pengungkapan diri di media sosial yaitu sebagai sarana pengungkapan kenangan, pikiran, perasaan, minat, opini dan konten-konten yang menjelaskan kehidupan penggunanya dengan menggambarkan siapa orang itu tanpa mengungkapkan identitas yang sebenarnya. Faktor lainnya mereka melakukan pengungkapan diri untuk berbagi tentang identitas pribadi mereka seperti gambar bahkan status hubungan. Selain itu juga ditemukan bahwa seseorang yang memiliki harga diri yang rendah cenderung menggunakan media sosial untuk meningkatkan citra diri mereka, membantu mereka mengatasi perasaan rendah diri melalui penguatan identitas sosial mereka.

Penggunaan media sosial dilakukan sebagai tempat untuk berinteraksi dan menjalin hubungan dengan orang lain di dunia maya. Sears, Freedman dan Peplau (1985) menjelaskan adanya afiliasi atau kebutuhan untuk membina hubungan dengan orang lain yang tidak terpenuhi oleh seorang individu mengakibatkan kesepian. Kesepian merupakan kegelisahan yang dirasakan seorang individu saat hubungan sosial mengalami kehilangan ciri-ciri penting.

Kesepian hampir dialami oleh seorang individu pada setiap masa perkembangan, seperti salah satunya terjadi pada masa dewasa. Adapun kesepian yang dirasakan dapat berupa kesepian emosional maupun sosial. Kesepian emosional terjadi karena ketiadaan figur kasih sayang yang intim. Sedangkan kesepian sosial terjadi pada seorang yang terintegrasi secara sosial atau komunikasi (dalam Sears, Freedman \& Peplau 1985). Santrock (2002) menjelaskan kesepian yang dialami oleh dewasa disebabkan oleh beberapa faktor seperti kurangnya waktu dalam berhubungan baik dengan perempuan atau laki-laki dihubungkan dengan perasaan kesepian. Penelitian yang dilakukan oleh Jenny de Jong-Gierveld (dalam Myers, 2012) pada dewasa menunjukkan bahwa kesepian sering kali dialami oleh orang yang tidak menikah dan belum menikah. Berdasarkan hasil survei yang dilakukan oleh Badan Pusat Statistik (BPS) menjelaskan penduduk Indonesia yang belum menikah atau lajang memiliki indeks yang lebih tinggi dengan jumlah 
71,53\% dibandingan dengan penduduk yang memiliki status perkawinan (dalam katadata.co.id, 2017).

Tingginya penggunaan internet khususnya media sosial oleh pengguna yang telah memasuki fase dewasa tentu akan berpengaruh pada interaksi sosial yang dilakukan. Ahmad, Mustafa \& Ullah (2016) menjelaskan dalam penelitannya intensitas seorang individu dalam mengakses media sosial kurang lebih antara 30 hingga 120 menit perhari. Dengan diketahuinya intensitas penggunaan media sosial dapat diindikasi bahwa kesepian yang dialami akan meningkatkan penggunaan media sosial. Hal ini sejalan dengan penelitian yang dilakukan oleh Pittman \& Reich (2016) hasilnya dapat diketahui bahwa individu yang merasa kesepian lebih cendrung menggunakan media sosial berbasis gambar seperti instagram dan snapchat sebagai media yang dapat mengurangi rasa kesepian dibandingkan dengan media sosial yang berbasis teks seperti facebook dan yik yak. Hasil peneitian juga menjelaskan dengan mengakses media sosial kesepian dapat berkurang, sementara kepuasan dan kebahagiaan bisa meningkat.

Kesepian yang dialami oleh seorang individu dianggap akan mampu meningkatkan keterbukaan diri di media sosial. Hal ini sejalan dengan penelitian yang dilakukan oleh Blachnio, Przepiorka, Balakier, \& Boruch (2016) yang menyatakan bahwa seorang individu meletakan informasi pribadi mereka pada media sosial karena mengalami perasaan kesepian dan seorang individu yang merasa kesepian melakukan pengungkapan diri berupa informasi lebih banyak pada facebook dibandingkan dengan individu lain yang tidak merasakan perasaan kesepian.

Berdasarkan uraian diatas menyebutkan bahwa pengungkapan diri seorang individu di media sosial disebabkan oleh kesepian, sedangkan dewasa yang belum menikah merupakan individu yang sering merasa kesepian dengan melakukan kegiatan pengungkapan diri di instagram untuk mengurangi perasaan kesepiannya. Hal ini yang menjadi alasan peneliti untuk meneliti hubungan antara kesepian dengan pengungkapan diri di instagram pada dewasa yang belum menikah. Selain itu didasarkan dengan melihat perkembangan media sosial yang terus berkembang khususnya pada instagram menjadi alasan pentingnya penelitian ini dilakukan. Penelitian ini juga diharapkan mampu berdampak dalam pengambilan keputusan pada penggunaan media sosial instagram yang terus berkembang dengan demikian seseorang mampu untuk mengembangkan sumber daya pribadi dalam pemenuhan tujuan hidupnya.

Adapun perbedaan penelitian yang akan dilakukan terletak pada penggunaan media sosial yang lebih dikhususkan pada instagram dengan subjek penelitian merupakan pengguna media sosial yang memasuki fase usia dewasa, memiliki usia diluar idealnya seorang individu membuat komitmen dan berstatus belum menikah. Pada penelitan sebelumnya meneliti hubungan kesepian dengan pengungkapan diri di media sosial facebook sedangkan penelitian yang akan dilakukan adalah untuk meneliti hubungan kesepian dengan pengungkapan diri di instagram pada dewasa yang belum menikah.

Adapun rumusan masalah yang akan diangkat dalam penelitian ini adalah apakah ada hubungan antara kesepian dengan pengungkapan diri di instagram pada dewasa yang belum menikah? Tujuan penelitian ini yaitu untuk mengetahui bagaimana hubungan antara kesepian dengan pengungkapan diri di instagram pada dewasa yang belum 
menikah. Adapun penelitian ini memiliki manfaat teoritis dan praktis. Manfaat teoritis penelitian ini diharapkan dapat menambah dan memperkaya temuan pada bidang ilmu psikologi sosial mengenai pengungkapan diri dan kaitannya dengan kesepian pada dewasa yang belum menikah, dan manfaat praktis dari penelitian ini diharapkan dapat memberikan informasi kepada pengguna instagram yang memasuki usia dewasa yang belum menikah.

\section{METODE}

Penelitian ini menggunakan metode kuantitatif dengan menggunakan desain korelasional. Margono (dalam Darmawan, 2013) penelitian kuantitatif adalah suatu proses menemukan pengetahuan menggunakan data berupa angka sebagai alat menemukan keterangan mengenai apa yang diinginkan sedangkan desain korelasional yaitu metode yang digunakan untuk menggambarkan asosiasi atau relasi variabel dengan variable lainnya.

Populasi dari penelitian ini adalah pengguna media sosial instagram yang belum menikah. Adapun teknik pengambilan sempel menggunakan nonprobability sampling dengan jenis purposive sampling. Darmawan (2013) menjelaskan nonprobability sampling adalah teknik pengambilan sampel yang tidak memberikan peluang kesempatan sama bagi setiap unsur atau anggota populasi untuk dipilih menjadi sampel. Teknik ini digunakan ketika tidak memiliki data pasti mengenai ukuran populasi dan kurangnya informasi lengkap mengenai elemen populasi. Sedangkan purposive sampling adalah teknik penentuan sampel dengan pertimbangan tertentu (dalam Sugiyono, 2012). Pada penelitian ini pertimbangan yang dilakukan yaitu dengan memperhatikan kriteria individu yang telah melewati fase membentuk komitmen dalam hubungan dengan usia minimal 25 tahun, belum menikah, menggunakan atau mengetahui media sosial instagram dengan jumlah subjek 260 orang.

Penelitian ini menggunakan dua variabel, yakni variabel bebas $(\mathrm{X})$ dan variabel terikat (Y). Adapun yang menjadi variabel bebas (X) (independent) adalah kesepian dan variabel terikat $(\mathrm{Y})$ (dependent variable) yakni pengungkapan diri. Pengungkapan diri yang dimaksud dalam penelitian ini yaitu penyampaian perilaku, sikap, perasaan, keinginan, motivasi dan ide yang bersifat faktual kepada orang lain di instagram. Adapun penyampaian informasi yang dilakukan dapat berupa gambar, video berdurasi pendek dan teks yang dapat dilakukan melalui fitur yang telah disediakan instagram.

Kesepian yang dimaksud dalam penelitian ini adalah perasaan yang dialami oleh seorang individu berupa kegelisahan dan ketidakpuasan pada seorang dewasa belum menikah terhadap perasaan khawatir tidak memiliki hubungan dengan orang lain. Dewasa belum menikah pada penelitian ini adalah seorang pengguna media sosial terutama instagram laki-laki atau perempuan, telah melewati fase untuk membentuk sebuah komitmen dalam 
hubungan yang salah satunya dipenuhi melalui pernikahan dan memiliki status belum menikah dengan usia diatas 25 tahun.

Pengungkapan diri diukur dengan menggunakan skala yang diadaptasi dan disusun beradasarkan dari 5 aspek pengungkapan diri oleh Wheeles (dalam Leung, 2002) yaitu kedalam dan intimasi (6 item), ketepatan dan kejujuran (4 item), jumlah (1 item), valensi (3 item), serta tujuan ( 2 item) berjumlah 16 item dengan reliabilitas 0,819 dan validitas 0,331-0,595. Contoh item yang digunakan "saya sering membicarakan perasaan saya di instagram". Skala ini berupa skala likert yang terdiri dari 5 poin berupa sangat setuju, setuju, netral, tidak setuju dan sangat tidak setuju. Adapun skala yang digunakan pada penelitian ini dengan menggunakan perkembangan dari penelitian Wheeless \& Grotz (1976), dan digunakan sebagai acuan pada penelitian Leung (2002) yang membahas pengungkapan diri pada pengguna ICQ (perangkat lunak yang digunakan untuk mengirimkan pesan). Penggunaan skala ini juga dikembangkan secara spesifik pada pengungkapan diri di instagram oleh Al-Kandari, dkk (2016). Sedangkan kesepian diukur dengan menggunakan skala UCLA yang disusun dan diadaptasi berdasarkan 3 aspek kesepian oleh Russel (1996) yaitu kepribadian (4 item), keinginan sosial (7 item), depresi (6 item) berjumlah 17 item dengan reliabilitas 0,859 dan validitas 0,319-0,694. Contoh item yang digunakan "seberapa sering Anda merasa sendiri". Skala ini berupa skala likert yang terdiri dari 4 poin berupa tidak pernah, jarang, kadang-kadang dan selalu yang dirasakan selama enam bulan terakhir. Adapun perkembangan penggunaan skala ini ada pada penelitian Sari \& Listiyandini (2015) yang meneliti tentang hubungan resiliensi dengan kesepian pada dewasa muda lajang dan pada penelitian Nurlayli \& Hidayati (2014) yang membahas kesepian pada pemilik hewan peliharaan yang tinggal jauh dengan keluarga. -

Penelitian dilakukan melalui penyebaran skala pada pengguna media sosial instagram dengan memberikan skala pengungkapan diri dan kesepian. Melakukan analisa hasil data yang didapatkan dari penyebaran dua skala dengan prosedur data-data yang telah diperoleh lalu kemudian dimasukan kedalam Microsoft Excel dan diolah menggunakan Statistical Package For Social Sciense (SPSS) versi 23. Peneliti menggunakan analisa uji korelasi spearman. Sugiyono (2012) menjelaskan korelasi digunakan untuk mencari hubungan dan membuktikan hipotesis hubungan dua variabel sedangkan analisa spearman digunakan untuk analisa data yang tidak harus berdistribusi normal pada kedua variabel. Selanjutnya, peneliti melakukan pembahasan analisa dan diskusi lalu kemudian membuat kesimpulan penelitian.

\section{HASIL}

Berdasarkan hasil analisa data dari penelitian yang telah dilakukan terhadap 260 responden dapat diketahui hasil uji korelasional menggunakan spearman pada data penelitian yang telah dilakukan maka dapat diketahui bahwa nilai $(\alpha=0,073)$ dan koefisien korelasi sebesar -0,111. Hasil ini menunjukan bahwa kedua variabel tidak ada hubungan yang signifikan dengan lemahnya tingkat hubungan antar variabel (syarat ada hubungan $\alpha=<0,05)$. 
Tabel 1. Hasil Uji Korelasional Spearman

\begin{tabular}{lcc}
\hline \multicolumn{1}{c}{ Keterangan } & Kesepian & Pengungkapan Diri \\
\hline Koefisien Korelasi & & \\
Sig. (2-tailed) & $-0,111$ & $-0,111$ \\
& 0,073 & 0,073 \\
\hline
\end{tabular}


Tabel 2. Tabulasi Skala Kesepian dan Pengungkapan Diri

\begin{tabular}{|c|c|c|c|c|c|c|c|c|c|c|c|c|}
\hline \multirow[t]{3}{*}{ Kategori } & \multicolumn{6}{|c|}{ Kesepian } & \multicolumn{6}{|c|}{ Pengungkapan Diri } \\
\hline & \multicolumn{2}{|c|}{ Tinggi } & \multicolumn{2}{|c|}{ Sedang } & \multicolumn{2}{|c|}{ Rendah } & \multicolumn{2}{|c|}{ Tinggi } & \multicolumn{2}{|c|}{ Sedang } & \multicolumn{2}{|c|}{ Rendah } \\
\hline & $\sum$ & $\%$ & $\sum$ & $\%$ & $\sum$ & $\%$ & $\sum$ & $\%$ & $\sum$ & $\%$ & $\sum$ & $\%$ \\
\hline \multicolumn{13}{|l|}{ Jenis Kelamin } \\
\hline Perempuan & $\begin{array}{l}84 \\
38 \\
\end{array}$ & $\begin{array}{l}46 \% \\
48 \%\end{array}$ & $\begin{array}{c}10 \\
3\end{array}$ & $\begin{array}{l}6 \% \\
4 \%\end{array}$ & $\begin{array}{l}87 \\
38 \\
\end{array}$ & $\begin{array}{l}48 \% \\
48 \%\end{array}$ & $\begin{array}{l}94 \\
36\end{array}$ & $\begin{array}{l}52 \% \\
45 \%\end{array}$ & $\begin{array}{l}9 \\
6\end{array}$ & $\begin{array}{l}5 \% \\
8 \%\end{array}$ & $\begin{array}{l}78 \\
37 \\
\end{array}$ & $\begin{array}{l}43 \% \\
47 \%\end{array}$ \\
\hline \multicolumn{13}{|l|}{ Usia } \\
\hline \multicolumn{13}{|l|}{ 25-29 } \\
\hline 30-34 & 118 & $50 \%$ & 13 & $6 \%$ & 105 & $44 \%$ & 119 & $50 \%$ & 11 & $5 \%$ & 106 & $45 \%$ \\
\hline$>35$ & 8 & $47 \%$ & 1 & $6 \%$ & 8 & $47 \%$ & 6 & $35 \%$ & 4 & $24 \%$ & 7 & $41 \%$ \\
\hline & 3 & $43 \%$ & 1 & $14 \%$ & 3 & $43 \%$ & 3 & $43 \%$ & 1 & $14 \%$ & 3 & $43 \%$ \\
\hline \multicolumn{13}{|l|}{ Suku } \\
\hline \multicolumn{13}{|l|}{ Pulau Jawa dan Madura } \\
\hline Bali dan Nusa Tenggara & 72 & $44 \%$ & 11 & $7 \%$ & 79 & $49 \%$ & 80 & $49 \%$ & 6 & $4 \%$ & 76 & $47 \%$ \\
\hline Kalimantan & 33 & $49 \%$ & 3 & $4 \%$ & 32 & $47 \%$ & 29 & $43 \%$ & 8 & $12 \%$ & 31 & $46 \%$ \\
\hline Sulawesi & 6 & $46 \%$ & 1 & $8 \%$ & 6 & $46 \%$ & 5 & $38 \%$ & 2 & $15 \%$ & 6 & $46 \%$ \\
\hline Lainnya & 5 & $46 \%$ & 2 & $18 \%$ & 4 & $36 \%$ & 4 & $36 \%$ & 2 & $18 \%$ & 5 & $46 \%$ \\
\hline & 2 & $33 \%$ & 0 & $0 \%$ & 4 & $67 \%$ & 3 & $50 \%$ & 0 & $0 \%$ & 3 & $50 \%$ \\
\hline \multicolumn{13}{|l|}{ Pekerjaan } \\
\hline Mahasiswa & 85 & $46 \%$ & 12 & $7 \%$ & 87 & $47 \%$ & 74 & $40 \%$ & 22 & $12 \%$ & 88 & $48 \%$ \\
\hline Tidak Bekerja & 28 & $45 \%$ & 4 & $6 \%$ & 31 & $49 \%$ & 31 & $49 \%$ & 2 & $3 \%$ & 30 & $48 \%$ \\
\hline & 6 & $46 \%$ & 1 & $8 \%$ & 6 & $46 \%$ & 6 & $46 \%$ & 3 & $23 \%$ & 4 & $31 \%$ \\
\hline
\end{tabular}


Pada tabulasi penggunaan media sosial, responden penelitian rata-rata memiliki 4-6 jenis media sosial dengan jenis media sosial yang paling sering digunakan adalah instagram dan waktu yang dibutuhkan untuk mengakses media sosial lebih dari 6 jam dalam satu hari penuh.

Tabel 3. Skor Skala Kesepian dan Pengungkapan Diri

\begin{tabular}{ccc} 
Kategori & Frekuensi & Presentase \\
\hline Kesepian & 124 & $48 \%$ \\
Tinggi & 14 & $5 \%$ \\
Sedang & 122 & $47 \%$ \\
Rendah & & \\
Pengungkapan Diri & 103 & $40 \%$ \\
Tinggi & 30 & $11 \%$ \\
Sedang & 127 & $49 \%$ \\
Rendah & & \\
\hline
\end{tabular}

Tabel 3 menunjukkan bahwa kesepian pada dewasa awal yang belum menikah cenderung tinggi dengan persentase sebesar $48 \%$. Kemudian, pengungkapan diri diketahui cenderung rendah dengan persentase sebesar $49 \%$.

\section{DISKUSI}

Hasil analisa data penelitian yang telah dilakukan dapat menunjukkan bahwa tidak adanya hubungan positif antara kesepian dengan pengungkapan diri $(\alpha=0,073)$. Analisa menunjukkan semakin tinggi kesepian maka semakin rendah pengungkapan diri dan semakin rendah kesepian maka semakin tinggi pengugnkapan diri (koefisian korelasi = 0,111). Hasil penelitian ini menolak atau tidak membuktikan hipotesa penelitian yang menyatakan bahwa ada hubungan positif antara kesepian dengan pengungkapan diri yang berarti bila suatu variabel ditingkatkan, maka akan meningkatkan variabel lain, dan begitu sebaliknya. Dengan tidak terbuktinya hipotesa, maka kesepian yang dirasakan oleh seorang individu yang belum menikah tidak dapat meningkatkan pengungkapan diri di instagram.

Hasil penelitian ini tidak sejalan dengan penelitian sebelumnya yang dilakukan oleh Blachnio, dkk (2016) dengan menunjukan hubungan positif pada kesepian dan pengungkapan diri yang dilakukan pada kelompok mahasiswa. Pada hasil penelitian ini menunjukkan orang-orang yang memiliki usia lebih muda memiliki nilai lebih tinggi karena kesepian diusia yang lebih muda dianggap sebagai alasan seorang individu banyak melakukan pengungkapan diri di media sosial.

Penelitian lain yang juga juga tidak sejalan dengan penelitian ini dilakukan dilakukan oleh Lee, Noh \& Koo (2013) pada kelompok mahasiswa dengan menunjukkan bahwa 
kesepian memiliki hubungan yang positif. Hasil penelitian menunjukkan bahwa responden yang memiliki perasaan kesepian umumnya terdiri dari mahasiswa yang sedang mengalami hubungan gagal dengan tidak memiliki keterampilan sosial untuk melakukan pengungkapan diri secara langsung pada hubungannya, sehingga mereka lebih cenderung menggunakan situs jejaring sosial untuk mengatasi ketidak mampuan dalam mengungkapkan diri secara langsung dalam kegagalan hubungan yang dialami.

Hasil penelitian yang telah dilakukan berbanding terbalik dengan penelitian sebelumnya karena pada penelitian ini tidak memperhatikan status hubungan seperti lajang atau sudah memiliki calon pendamping hidup (kekasih) pada responden yang belum menikah. Status hubungan ini dianggap berkaitan dengan teori yang dikemukakan Weiss (dalam Brehm, 2002) yang menjelaskan jenis kesepian berupa isolasi sosial dan emosional yang menyatakan bahwa seorang individu merasakan kesepian karena kurang memiliki jaringan sosial yang luas, pasangan romantis dan hubungan yang intens. Sedangkan Dayakisni \& Hudaniah (2009) menyatakan bahwa orang-orang yang bercerai atau gagal dalam menjalin hubungan dianggap paling merasakan kesepian.

Selain itu juga pada kelompok usia muda bahkan mahasiswa pada penelitian yang telah dilakukan ataupun penelitian-penelitian sebelumnya, sekitar usia awal masa dewasa menurut Erikson (dalam Santrock, 2011) adalah masa seorang individu memasuki fase dimana mereka lebih sering untuk melakukan keterbukaan diri (self-disclosure) dan berbagi pikiran-pikiran personal kepada orang lain sebagai tanda sebuah keintiman. Keintiman yang dilakukan oleh seorang individu juga merupakan sebuah proses menemukan diri sendiri dan peleburan diri di dalam diri orang lain yang membutuhkan sebuah komitmen. Ketidak mampuan mengembangkan relasi yang bermakna dengan orang lain dapat melukai seorang individu dan jika hal itu terjadi maka lambat laun akan mundur kedalam pencarian diri dan kadangkala mengarah pada depresi yang menyebabkan isolasi.

Pada hasil penelitian ini juga selaras dengan penelitian yang dilakukan oleh Al-Saggaf dan Nielsen (2014) yang bertujuan untuk menentukan hubungan antara kesepian dengan keterbukaan diri pada situs jejaring sosial facebook pada responden yang dispesifikasikan menurut jenis kelamin yaitu wanita dengan menunjukkan bahwa tidak ada hubungan yang signifikan antara variabel kesepian dengan pengungkapan diri. Wanita yang memiliki perasaan kesepian lebih mengungkapkan jenis informasi pribadi mereka berupa alamat, hubungan relasi dengan orang yang terhubung pada situs jejaring sosial. Sedangkan pada penelitian yang telah dilakukan juga memiliki kesamaan pada penelitian sebelumnya dengan menspesifikasikan responden yang memiliki status belum menikah dan telah melewati fase idealnya membentuk sebuah komitmen.

Penelitan ini juga ditemukan fakta-fakta lain seperti jenis kelamin responden yang belum menikah mayoritas terdiri dari laki-laki dibandingkan dengan perempuan. Santrock (2011) menjelaskan dibeberapa daerah di luar negeri seperi Denmark dan Hungaria memiliki presntase jumlah laki-laki yang belum menikah lebih tinggi dibandingkan dengan seorang individu yang berjenis kelamin wanita. Dijelaskan juga pada sesorang individu yang telah memasuki fase dewasa terutama diawal hingga pertengahan usia dua puluhan banyak dimulai untuk menyelesaikan pendidikan bahkan hingga membentuk 
awal sebuah karir. Hal ini juga senadada dengan temuan dalam penelitian bahwa status pekerjaan responden yang sudah bekerja memiliki jumlah yang tinggi diikuti dengan status sebagai mahasiswa.

\section{SIMPULAN DAN IMPLIKASI}

Penelitian yang telah dilakukan membuktikan bahwa hasil memiliki ketidaksesuaian dengan hipotesa, yang artinya bahwa penelitian ini membuktikan kesepian tidak memiliki hubungan dengan pengungkapan diri.

Implikasi dari penelitian ini meliputi pengambilan responden penelitian harus memperhatikan status hubungan seperti lajang, sudah menikah, bercerai, atau sudah memiliki calon pendamping, pilahan usia, serta pada penggunaan variabel kesepian dan pengungkapan diri umumnya tidak disertakan dalam penggunaan media sosial melainkan pada kehidupan interaksi intrpersonal seorang individu di dunia nyata. Sehingga diharapkan mampu memberikan informasi kepada para responden yang telah memasuki usia dewasa dan belum menikah. Selain itu, bagi penelitian selanjutnya dapat mempertimbangkan penggunaan variabel lain seperti harga diri dan kontrol diri yang mempengaruhi pengungkapan diri dan tidak hanya melihat dari penggunaan media sosial tetapi kehidupan interaksi sehari-hari di dunia nyata sehingga penggunaan subjek juga mampu lebih banyak serta diharapkan dapat membuktikan adanya hubungan antara kesepian dan pengungkapan diri.

\section{REFERENSI}

Ahmad, S., Mustafa, M., \& Ullah, A. (2016). Association of demographics, motives and intensity of using social networking sites with the formation of bonding and bridging social. Journal Computers in Human Behavior, 57, 107-114.

Al-Kandari, A., Melkote, S. R., \& Sharif, A. (2016). Needs and motives of instagram users that predict self-disclosure use: A case study of young adults in Kuwait. Journal of Creative Communications, 11, (2), 85-101.

Al-Saggaf, Y., \& Nielsen, S. (2014). Self-disclosure on facebook among female users and its relationship to feelings of loneliness. Journal Computers in Human Behavior, 36, 460-468.

Alwisol. (2008). Psikologi kepribadian. Malang: UMM Press

APJJI. (2016). Survei internet APJII 2016. Diakses tanggal 1 Maret 2018 dari https://apjii.or.id/content/read/39/264/Survei-Internet-APJII-2016

Baron, R. A., \& Byrne, D. (2005). Psikologi sosial. (Terj. Ratna Djuwita, Melania Yasmina, Lita P. Lunanta). Edisi 10 Jilid 1 dan 2, Jakarta: Erlangga

Brehm, S.E. (2002). Intimate relationship. New York: Mc-Grow Hill 
Bkkbn. (2017). Usia pernikahan ideal. Diakses tanggal 29 Januari 2018 dari https://www.bkkbn.go.id/detailpost/bkkbn-usia-pernikahan-ideal-21-25-tahun

Blachnio, A., Przepiorka, A., Balakier, E., \& Boruch, W. (2016). Who discloses the most on facebook?. Journal Computers in Human Behavior, 55, 664-667.

Blachnio, A., \& Przepiorka, A. (2016). Dysfunction of self-regulation and self-control in facebook addiction. Original Paper, 87, 493-500.

Darmawan, D. (2013). Metode penelitian kuantitatif. Bandung: Remaja Rosdakarya

Dayakisni, T., \& Hudaniah. 2009. Psikologi sosial. Malang: UMM Press

DeGenofa, M. K. (2008). Intimate relationships, marroages and families. New York: McGraw-Hill.

DeVito, J. A. (1989). The interpersonal communication book. Edisi 5, London: Harper dan Row

DeVito, J. A. (2012). The interpersonal communication book. Edisi13, Amerika: Pearson Education

Dinas Kependudukan dan Pencatatan Sipil Kabupaten Lombok Barat. (2018). Rekapitulasi laporan pelaksanaan administrasi kependudukan Dinas Kependudukan dan Pencatatan Sipil Kabupaten Lombok Barat Keadaan sampai dengan Tanggal 28 Desember 2017

Farber B. A., \& Nitzburg G. C. (2016). Young adult self disclosures in psychotherapy and on facebook. Journal Counselling Psychology Quarterly, 29, (1), 76-89.

Feldman, R. S. (2012). Pengantar psikologi. (Terj. Petty Gina Gayatri, Putri Nurdina Sofyan). Edisi 10 Jilid 2, Jakarta: Salemba Humanika

Fisher, B. A. (1990). Teori-teori komunikasi. (Terj. Soejono Trimo). Bandung: PT. Remaja Rosdakarya

Instagram-press (2016). Instagram today: 500 million windows to the world. Diakses Tanggal 1 Februari 2018 dari https://instagram-press.com/id/our-story/

Instagram-press (2017). Menjadikan instagram sebagai tempat yang aman untuk berekspresi diri. Diakses 3 Februari dari https://instagram-press.com/id/our-story/

Katadata.co.id. (2017). BPS. Indeks kebahagiaan Indonesia naik, orang lajang paling bahagia. Diakses Tanggal 20 Februari 2018 dari https://katadata.co.id/berita/2017/08/15/bps-indeks-kebahagiaan-indonesia-naikorang-lajang-paling-bahagia

King, L. A. (2016) Psikologi umum. (Terj. Petty Gina Gayatri). Edisi 3 Jilid 1, Jakarta: Salemba Humanika

Kominfo. (2013). Pengguna internet di Indonesia 63 juta orang. Diakses Tanggal 29 Desember 
https://kominfo.go.id/index.php/content/detail/3415/Kominfo+\%3A+Pengguna+Int ernet+di+Indonesia+63+Juta+Orang/0/berita_satker

Lake, T. (1986). Kesepian. Jakarta: Arcan.

Lee, K.T., Noh, M.J., \& Koo, D.M. (2013). Lonely people are no longer lonely on social networking sites the mediating role of self-disclosure and social support. Jurnal Cyberpsychology, Behavior, and Social Networking, 16, (6).

Leung, L. (2002). Loneliness, self-disclosure, and ICQ ("I seek you") use. Journal Cyberpsychology \& behavior, 5, (2).

Mafazi, N., \& Nuqul, F. L. (2017). Perilaku virtual remaja strategi coping, harga diri dan pengungkapan diri dalam jejaing sosial online. Jurnal Psikologi, 16, (2), 128-137.

Myers, D. G. (2012). Psikologi sosial. (Terj. Aliya Tusyani, dkk). Edisi 10 Jilid 2, Jakarta: Salemba Humanika.

Nurlayli, R. K., \& Hidayati, D. S. (2014). Kesepian pemilik hewan peliharaan yang tinggal terpisah dari keluarga. Jurnal Ilmiah Psikologi Terapan, 2, (1).

Pittman, M., \& Reich, B. (2016). Social media and loneliness: Why an instagram picture may be worth more than a thousand twitter words. Journal Computers in Human Behavior, 62, 155-167.

Prawesti, F. S., \& Dewi, D. K. (2016). Self esteem dan self disclosure pada mahasiswa psikologi pengguna blackberry massager. Jurnal Psikologi Teori dan Terapan, 7, (1).

Russel, D. W. (1996) UCLA lonelines scale (Version 3): Relability, validity and factor structure. Journal of Personality Assesment, 66, (1), 20-40.

Santrock, J. W. (2002). Life-span development perkembangan masa hidup. (Terj. Achmad Chusairi \& Juda Damanik). Edisi 5 Jilid 2, Jakarta: Erlangga.

Santrock, J. W. (2012). Life-span development: Perkembangan masa hidup. (Terj. Benedictine Widyasinta). Edisi 13 Jilid 1 dan 2, Jakarta: Erlangga.

Sari, I. P., \& Listiyandini, R. A. (2015). Hubungan antara resiliensi dengan kesepian (loneliness) pada dewasa muda lajang. Journal Prosiding Pesat, 6

Sears, D. O., Freedman, J. L., \& Peplau, L. A. (1985). Psikologi sosial. (Terj. Michael Adryanto \& Savitri Soekrisno). Edisi 5 Jilid 1, Jakarta: Erlangga.

Sembiring, K. D. R. (2017). Hubungan antara kesepian dan kecendrungan narsistik pada pengguna jejaring sosial media instagram. Jurnal Psikologi, 16, (2), 147-154.

Sugiyono. (2012). Statistika untuk penelitian. Bandung: Alfabeta

Taylor, S. E., Peplau L. A., \& Sears, D. O. (2009). Psikologi sosial. (Terj. Tri Wibowo B.S.) Edisi 12, Jakarta: Kencana Prenada Media Group. 
Tribunnews. (2017) Curhatan Lyra Virna di instagram yang dilaporkan polisi. Diakses 28 Januari 2018 dari http://www.tribunnews.com/seleb/2017/10/10/curhatan-lyravirna-di-instagram-inilah-yang-yang-dilaporkan-ke-polisi

Tribunnews. (2018) Bermula dari postingan viral inikah tanda mpok Alpa Ketian Rejeki menuju layar TV. Diakses 28 Januari 2018 dari http://www.tribunnews.com/seleb/2018/01/24/bermula-dari-postingan-viralinikah-tanda-mpok-alpa-ketiban-rejeki-menuju-layar-tv

Varnali, K., \& Toker, A. (2015). Self disclusure on social networking sites. Journal Social Behavior and Personality, 43, (1), 1-14.

Wheeles, L. R., \& Grotz, J. (1976). Conceptualization and measurement of reported selfdisclosure. Human Communication Research, 2, 338-346. 